\title{
Friedrich Halm's Earliest Extant, Melodramatic Novelle, St. Sylvesterabend: An Austrian Dramatist's Hidden Beginnings as a Narrative Fiction Writer
}

\author{
Tony Page (โทนี่ เพจ) \\ D.Phil., Oxon, a Lecturer in English and European Literature, School of \\ Humanities, Bangkok University, Bangkok, Thailand \\ tny7tny7@fastmail.fm
}

\begin{abstract}
To date there has been no scholarly exploration of the genesis and nature of Friedrich Halm's earliest extant Novelle, St. Sylvesterabend (New Year's Eve). The present research article attempts to fill that gap by determining the contested date of the story's origin, establishing it as 1823. Furthermore, the article examines the tale's simplicity of style, which is distinct from Halm's later Kleist-influenced narratives. Furthermore, it analyzes the novel's structural principle of parallels and contrasts, and its themes of monomania, secularised religiosity, and Christian caritas. The article also indicates how vicious criticism of the tale by Halm's literary mentor, Michael Enk von der Burg, lacerated the young Halm's self-confidence as a Novelle writer and crippled his novelistic creativity for decades to come.
\end{abstract}

\section{Keywords}

Friedrich Halm - Michael Enk von der Burg - melodramatic Novelle - Austrian literature - St. Sylvesterabend - monomania/obsession - Christian caritas (love) 
บทคัดย่อ

เรื่องสั้นประโลมโลกที่เก่าที่สุดและยังหลงเหลืออยู่ของ Friedrich Halm: จุดเริ่มต้นที่ถูก ปกปิดของนักเขียนบทละครชาวออสเตรียในฐานะนักเขียนเรื่องอ่านเล่น

เนื่องจากปัจจุบันยังขาดการค้นคว้าทางวิชาการเกี่ยวกับต้นกำเนิดและคุณลักษณะของนวนิยาย ขนาดสั้นที่เก่าแก่ที่สุดซึ่งยังหลงเหลืออยู่ของ Friedrich Halm เรื่อง St. Sylvesterabend บทความ วิจัยชิ้นนี้จึงมีวัตถุประสงค์เพื่อเติมเต็มช่องว่างด้วยการสืบค้นวันเวลาที่งานชิ้นนี้ถือกำเนิดขึ้น ซึ่งยัง เป็นประเด็นที่ถกเถียงกันอยู่ โดยเสนอว่าผลงานดังกล่าวกำเนิดขึ้นในปี 1823 นอกจากนี้ บทความนี้ ยังวิเคราะห์รูปแบบการเขียนที่เรียบง่ายของนวนิยายเรื่องนี้ ซึ่งเป็นลักษณะที่แตกต่างจากงานเขียน ของ Halm ในช่วงหลังที่ได้รับอิทธิพลจาก Kleist รวมถึงวิเคราะห์หลักการเชิงโครงสร้างของ ความเหมือนและความต่าง และวิเคราะห์แก่นเรื่องเกี่ยวกับความหมกมุ่นลุ่มหลงในสิ่งเดียว ศาสนา แบบฆราวาส และความรักแบบชาวคริสต์ นอกจากนี้ บทความยังชี้ให้เห็นว่าคำวิจารณ์อย่างรุนแรง ของ Michael Enk von der Burg ผู้เป็นพี่เลี้ยงทางวรรณกรรมของ Halm ได้ฉีกทึ้งความมั่นใจใน การเป็นนักเขียนนวนิยายของ Halm ในวัยหนุ่มและทำลายความคิดสร้างสรรค์ในการเขียน นวนิยายของเขาในอีกหลายทศวรรษต่อมาอย่างไร

\section{Introduction}

When the $19^{\text {th }}$-century Austrian dramatist, Friedrich Halm $(1806-1871$, real name: Eligius von Münch-Bellinghausen), published his crime Novelle (novella), Die Marzipan-Lise (English: Marzipan Lisa) in 1856, readers of German literature doubtlessly assumed it constituted this celebrated playwright's first major work of fiction. No other work of prose fiction had been published by this dramatist (it was almost exclusively as a dramatist that Halm was known) before that date. The Novelle itself was artistically noteworthy and has been described as one of the "Perlen deutschsprachiger Erzählkunst" (pearls of German language narrative art) (Pochlatko, Pongratz, and Koweindl 1963, 202).

By 1856 , Halm had already achieved pan-European celebrity as a playwright, particularly in Austria, Hungary, Germany, Italy and England, with his Griseldis of 1835 - which was praised by the illustrious Dichter (poets) Franz Grillparzer and Ludwig Tieck - and subsequently with Der Sohn der Wildnis (The Son of the Wilderness) in 1842. He would later be immortalised as a poet when a number of his poems were set to music by Johannes Brahms. He would further be memorialised by a stone bust atop Vienna's famous Burgtheater, and would in 1876 have a Viennese street (existent to this day) - the Halmgasse (Halm Alley) - named after him. His sentimental drama, Der Sohn der Wildnis, would even be referenced in 1846 by Karl Marx and Friedrich Engels in Die deutsche Ideologie (Marx and Engels 1969, 232), and in 1915 by the great Irish writer, James Joyce, in Portrait of the Artist as a Young Man (Joyce 2000, 82, alluding to Halm's play as Ingomar the Barbarian). The famous definition of love from 
that drama - "two souls with but a single thought,/ Two hearts that beat as one" - even found its way into popular English culture in the Francis Durbridge detective radio-drama, Paul Temple Intervenes, broadcast by ввс radio during World War II on Friday 30 October 1942 (Durbridge 1942); indeed, that romantic apothegm has long since become part of popular colloquial English discourse and was even on occasion quoted to me in my childhood and maturer years - if I might be permitted a personal reminiscence - by my own (English) mother, who had enjoyed only the scantiest literary education.

Long before that time Halm was already recognised in Germany and Austria as a Novellist (novella writer) of significance with the posthumous publication in 1872 of his fictional masterpiece, Das Haus an der Veronabrücke (The House by Verona Bridge): Paul Heyse wanted to include this Novelle in his landmark Deutscher Novellenschatz (Treasury of German Novellas), but decided that its sexually shocking subject matter forbade it. Bennett sympathises with that reticence, but speaks of the tale as being 'among the masterpieces of the nineteenth century' (Bennett 1961, 202). While Halm's earliest extant tale, St. Sylversterabend (New Year's Eve), is less accomplished, it yet displays thematic and structural merits which make it worthy of analysis.

It is the purpose of the present article to examine St. Sylvesterabend, which did not see publication until 2017, to determine the year of its genesis, comment on its themes and style, and to explain why this talented writer waited over two decades before returning to the field of narrative fiction in which he displayed such youthful promise.

The Dating of St. Sylvesterabend

Determining the precise year of the story's composition has proven problematic. Halm's literary executors, Faust Pachler and Emil Kuh, claim it was written in 1835 (Halm 1872a, x). Yet they overlook a major contradictory clue: in the correspondence between Halm and Michael Enk von der Burg (Halm's former school master and subsequent literary mentor), there exists a letter from Enk which mentions St. Sylvesterabend by name; that letter is dated 27 October 1833 (Schachinger 1890, 3). Evidently the story was already in existence by that date; Enk speaks of assessing it on Halm's request by early December 1833 (Schachinger 1890, 3).

In fact, the story had been written earlier. In the original handwritten MS which I examined under a powerful magnifying lens in Vienna's Nationalbibliothek (National Library), I found Halm had in fact appended, in small lettering, the date of the story's completion: "16 Sept. [1] 823". Halm was thus only 17 
years old at the time. This gives us a uniquely early glimpse into the creative workings of Halm's "novellistic" mind.

The Role of Michael Enk von der Burg regarding St. Sylvesterabend and Halm's Fiction Writing

It has been observed above that the MS of St. Sylvesterabend was forwarded by Halm to his former schoolmaster, Michael Enk von der Burg, for purposes of assessment. Enk and Halm had lost contact for many years, but in 1831, they met again and commenced a literary correspondence. The impact which Enk's caustic critique of the tale exerted upon the young writer was devastating: it shook his narratorial self-confidence to the core, to such an extent indeed that he never dared attempt another work of prose fiction until the year 1856 , when he wrote Die Marzipan-Lise and by which time Enk was long dead. It should be noted that Halm had written novellas and stories after St. Sylvesterabend (these include Das Auge Gottes, [The Eye of God] 1826, Ein Abend zu L. [An Evening in L.], 1828, and Die Abendgenossen [The Evening Companions], 1829), but after the renewed contact with Enk in 1831, Halm's fiction writing ceased for more than two decades.

While it might be argued that Enk (a drama enthusiast) had a positive influence upon Halm's development as a playwright (especially vis-à-vis Halm's Griseldis), it is also evident that this single-minded Benedictine monk determinedly deflected his young pupil away from fiction writing. Reinecke notes “... leider hat er [i.e. Enk] den Freund [i.e. Halm] immer nur auf das Drama gewiesen." (Unfortunately, he always steered Halm towards the drama) (Reinecke 1912,4). Yet it is precisely in the sphere of fiction - not drama - that Halm's greatest gifts lay; Wilpert, for example, ranks Halm's stories far higher in significance than his dramas, writing that Halm is "bedeutender und einheitlicher in seinen erst postum erschienenen realistischen Novellen um Abgründe des menschlichen Herzens ...", (more significant and more unified in his posthumous, realistic novellas circling upon the abysses of the human heart) (Wilpert 1976, 268).

Enk castigated the tale mercilessly, lambasting its grammar, style and narrative content. Enk's often petty and quibbling comments are scruffily scribbled all over Halm's MS (Faust Pachler aptly speaks of a "Versudelung seines Manuscriptes" (soiling of his MS) - Pachler 1877, 245), and those attacks on Halm's story are markedly lacking in tact and temperance; indeed, Enk accorded the tale so little esteem that he did not deem it worth the trouble to sharpen the pencil with which he scrawled down his excoriating comments: the handwriting is thick, blunt, and difficult to decipher. It is ironic that he complains 
elsewhere (correctly) about Halm's "ganz unleserliche Schrift" (completely illegible handwriting) (Schachinger 1890, 9), when his own is so challenging. He even goes so far as to say that while Halm's unclear handwriting usually disturbs the Unbefangenheit (natural flow) of the reading experience, this is not the case with St. Sylvesterabend - "der es wahrlich nicht verdiente" (which truly did not deserve it) (Schachinger 1890, 9). In other words, according to Enk, St. Sylvesterabend deserves no readership at all. This is a viewpoint which I decidedly do not share. It is also an assessment which Halm himself rejected, as in his Sendschreiben an J.C.R. (Letter to J.C.R.) of 1828 , he looks back at such early works as this, contemplates whether he should destroy them, but decides not to, saying, "ich halte sie für nicht ganz werthlos." (I do not regard them as wholly without value) (Halm 2012, loc. 243).

Pachler and Kuh comment upon the harshness of Enk's marginal notes in the following terms, "Enk's Randbemerkungen ... sind eben so derb als lehrreich und es ehrt den Schüler, daß er in Erwägung des hohen Zweckes sich diesen starken Ton gefallen ließ" (Enk's marginal comments ... are just as coarse as instructive, and it does honour to his pupil that he tolerated this strong tone in consideration of the high purpose) (Halm 1872a, $x$ ). The intention might have been "high", but most of Enk's comments smack of pettiness and pomposity. An example of Enk's needless fault-finding is provided when he writes a laconic Wer? (Who?) regarding the referent of a relative clause (where it is abundantly obvious which character Halm is referencing in that specific subordinate clause), or by the following scrappy and dismissive remarks:

Male; unedel; unpassend;?? Sic; ungelenk; spiace; familiäre Sprechart; Pomade - und zwar nicht von der besten; detto im Superlativ; verbraucht; male juncta; widerlich und unpassend zugleich; Komödienfluch; Puppenspielpathos; nicht viel besser; Worte! Worte! Worte!

(Bad; ignoble; inappropriate;?? sic. Clumsy; spiace; 'common' mode of speech; hair grease - and indeed not of the best variety; the same in the superlative; worn-out; male juncta; repugnant and simultaneously unsuitable; comedic curses; the pathos of a puppet play; not much better. Words! Words! Words!)

(Pachler 1877, 245)

It would appear that Halm, diffident by nature, lacked the inner vigour to strike back at Enk's disparaging comments (no St. Sylvesterabend correspondence from Halm exists); instead, Halm seemingly bore these scathing and wounding criticisms deep within himself for over two decades. Reinecke comments on the deplorable effect of Enk's comments on Halm's self-confidence: "Bei Halms 
hochgradigem Mangel an Selbstvertrauen ist es begreiflich, daß ihn die schonungslose Kritik Enks an seinem Erzählertalent verzweifeln ließ ... " (With Halm's low level of self-confidence it is understandable that this unsparing criticism by Enk caused him to despair of his narratorial talent) (Reinecke 1912, 3)

Reinecke writes perceptively here. Enk's excoriations of St. Sylvesterabend assuredly crippled Halm's novellistic creativity, and from the day of Enk's attacks in the early 1830 s until 1856, Friedrich Halm did not write another word of narrative fiction.

What type of story did Halm create in this tale of two obsessively feuding brothers? What might its literary taxonomical classification be? Pachler and Kuh call it a Novelle (Halm 1872a, x), as does Schachinger $(1890,3)$. Halm himself calls it a Skizze (sketch). According to the German Free Dictionary online, a Skizze is "ein kurzer Text, der sich auf das Wesentliche beschränkt und es nicht weiter ausarbeitet" (a short text which confines itself to the essential and does not elaborate further) (German Free Dictionary 2018). The Encyclopaedia Britannica defines a "sketch" as "a short prose narrative" (Encyclopaedia Britannica 2018), while The Shorter Oxford English Dictionary (Brown 2003, 2,856) states that it is "A brief ... narrative, giving minimum, essential, or prominent facts, incidents, etc.; a brief tale". This description would fit St. Sylvesterabend, which only runs to 9,380 words and focusses upon a very limited number of prominent plot-points and characters.

Yet the designation Novelle (novella) could also appropriately be applied; in this, Pachler is correct. According to Garland, the Novelle is marked by "concentrated presentation of an action which arouses suspense and contains an element of surprise leading to an unexpected ending" (Garland 1986, 674). Such a characterisation would certainly mirror St. Sylvesterabend's plot design, where the narrative is very concentrated in form and moves suspensefully forward towards its horrific, unerhörtes (unheard-of/shocking) end. The story, however, contains a good deal of dialogue, and to that extent possesses a dramatic quality. The plot itself becomes increasingly sensationalist and melodramatic, so that perhaps the most accurate description of the piece might be "a melodramatic sketch", or "a sensationalist melodrama in Novelle form". For the sake of brevity, however, I shall henceforth refer to it simply as a Novelle.

It is germane to note that the majority of Halm's later plays are in fact melodramas and are anticipated by this early literary blend of melodrama and Novelle, which presents the reader in embryonic form with some of the 
key thematic preoccupations of Halm's more mature writings, and displays considerable skill in engendering a brooding, uncanny atmosphere and bodying forth a plot and characters of a sensationalist hue.

It is a truism of Halm scholarship that as a Novelle writer Halm was stylistically influenced by the distinctive verbal patternings and syntactical convolutions of Heinrich von Kleist (Wilpert 1976, 268; Reinecke 1912, 19; Halm 1872b, vii). Even one of Halm's earliest Novellen, Das Auge Gottes, written in 1826, displays Kleistean influence. I have myself elsewhere remarked that Halm "out-Kleists Kleist" (Halm 2011, loc. 120; ${ }^{1}$ ) in his use of encapsulated subordinate clauses.

What is striking about St. Sylvesterabend, in contrast, is that for the first time we encounter a Halm whose narratorial style diverges from Kleist. In St. Sylvesterabend, the style is simple and direct, shorn of all complex syntactical structures; the narratorial viewpoint is an omniscient one, and the narrator allows himself slightly more moral-judgmental intrusions than the largely "bald reporting of the facts" that can typify Kleist's narrative stance (Allan 2001, 223-224). This suggests that it was not until the year 1824, 1825 or at the latest 1826 (in which latter year Halm wrote Das Auge Gottes) that the young Austrian engaged deeply and extensively with the (for him) paradigmatic master Novelle writer, Heinrich von Kleist.

A brief comparison of two or three passages from Halm's literary career might illustrate the change that Halm's style underwent. First, the opening sentences of St. Sylvesterabend (the slightly antiquated orthography is here and subsequently retained):

Es war am $30 t e n$ Dezember 1631 um fünf Uhr Abends. Der trübe unfreundliche Wintertag war zu Ende gegangen, und in den düstern Straßen Cöllns brütete nächtliche Dämmerung. Die Vesper war vorüber; aus den zahlreichen Kirchen strömte die andächtige Menge, und suchte klappernd vor Frost die warmen Stuben. Die dunklen Fenster der Häuser erhellten sich; aus den überfüllten Schenken scholl das verworrene Gemenge vieler Stimmen ...(Halm 2017, loc. 80-84).

1 All page references to Amazon Kindle e-books specify the 'location' within the e-book, which is equivalent to a conventional page number. 
(It was five o'clock in the evening, 30 December 1631. The overcast, unfriendly day was drawing to a close, and nocturnal twilight was brooding upon the gloomy streets of Cologne. Vespers was over. From out of the many churches streamed the devout crowd. Their teeth chattering with frost, they sought out their warm rooms. The dark windows became lit up, and from the crowded taverns emerged the confused sound of many voices ...).

The sentences are simple, straightforward, and uni-directional. There follows another example of that non-complex style, where Friar Placidus's arrival at the sinister Kleeborn residence is narrated:

der Mönch wurde von einem alten ergrauten Diener des Hauses empfangen, der auf seine Frage nach Herrn Egydius Kleeborn, stillschweigend mit seiner Leuchte auf die Treppe zuging, die in die oberen Gemächer des Hauses führte. Der Mönch folgte seinem stummen Führer.

Als sie die Treppen erstiegen hatten, wandelten sie lange Zeit in einem gewölbten Gange fort, aus dem rechts und links Thüren in die Wohnzimmer zu führen schienen. Im ganzen Haus brütete unheimliche Finsterniß; ein betäubend starker Weihrauchduft war ringsum verbreitet, und fernher aus den Hintertheilen des Gebäudes scholl ein dumpfes Gemurmel, wie von Bethenden. (Halm 2017, loc. 212)

(The monk was received by a grisly-haired servant of the house who, in response to his request for Herr Egydius Kleeborn, moved quietly with his lamp towards the staircase, which led to the house's upper chambers. The monk followed his silent leader. After they had climbed the stairs, they passed for a long while along a vaulted passageway, from which doors left and right seemed to lead into the living quarters. Uncanny darkness brooded inside the whole house. A strong, torpefying aroma of incense was diffused everywhere, and in the distance at the rear of the building could be heard dull mumbling, as of people praying).

As has been remarked by other scholars, one of Halm's central concerns is to generate atmosphere and "mood"; just as his dramas "legen den Hauptwert auf Stimmung und Gemüt' (place their main emphasis on mood and feeling) (Kosch 1963, 142), so too here. More pertinently, one can contrast the stylistic simplicity of the foregoing passages with the more convoluted and intertwined sentence structures of the later Das Haus an der Veronabrücke, the opening lines of which run as follows: 
Zu Venedig im Pfarrbezirke Santa Maria Zobenigo, hart an der Veronabrücke (Ponte della Verona), die von S. Fantino her über den Kanal, Rio menuo genannt, nach S. Benedetto und S. Lucia oder links hinüber nach S. Angelo und S. Stefano führt, stand noch im Anfange des 17.Jahrhunderts ein ansehnliches, palastartiges Gebäude. Die schmale, in den beiden oberen Stockwerken mit Balkonen und zierlichen Spitzbogenfenstern geschmückteVorderseite der Veronabrücke zukehrend, reichte es doppelt, ja dreifach so tief in das enge, kaum fünf Fuß breite Gäßchen hinein, das den Rio mueno mit dem damals noch offenen, jetzt zugeworfenen und in eine Straße verwandelten Kanal Rio degli assassini verbindet. (Halm 1872a, 125)

(In Venice, in the diocese of Santa Maria Zobenigo, hard by Verona Bridge (Ponte della Verona), which leads from San Fantino across the canal named the Rio menuo - to Santa Benedetto and Santa Lucia, or left across to Santa Angelo and Santa Stefano, there still remained standing at the beginning of the $17^{\text {th }}$ century an impressive, palace-like edifice. With its narrow façade - adorned on its two upper floors with balconies and delicate, pointed-arch windows - facing Verona Bridge, it extended double, indeed threefold, as deeply into the constricted little alleyway, scarcely five feet wide, which connects the Rio menuo with the then closed but now open and street-transformed canal, Rio degli assassini).

The syntax here, with its nominally pre-positioned adjectival attributes and paratactic concatenations, is positively confusing - deliberately so, to create a verbal analogue of the labyrinthine complexity of canals, alleyways and churches in Venice, to be sure, but also to convey a sense of the disorientating moral mazes of the world which characterize Halm's later vision in general. Heinrich von Kleist is certainly a part of the linguistic articulation of that vision - but in the earlier St. Sylvesterabend, Kleist has not yet become a detectable presence in Halm's verbal terrain.

Faust Pachler, together with Emil Kuh, was Friedrich Halm's literary executor. He found St. Sylvesterabend in MS form in Halm's Nachlass and wrote briefly of it:

Zwischen diesen beiden Dichtungen [i.e. the poems, 'Makame' and 'Beim Tod Kaiser Franz I'] fällt eine Erzählung - Skizze nennt er sie - 'St. Sylvesterabend' betitelt, die eine solche Uebereinanderhäufung des Gräßlichen 
bietet, daß ich ihrer nur um der Vollständigkeit willen erwähne. Sie verräth übrigens in der Technik bereits den Dramatiker, und zeigt im Styl ebenfalls schon jenen Drang nach Knappheit, der in den späteren Novellen so stark hervortritt ... (Pachler 1877, 244)

(Between these two poems comes a narrative - he calls it a 'sketch' entitled New Year's Eve, which offers up such an agglomeration of the Horrid that I only mention it here for the sake of completion. It does, however, already reveal in its technique the dramatist, and likewise shows in its style that drive towards skimpiness/compression, which comes to the fore so strongly in the later novellas ...)

Pachler is right to highlight the stylistic affinities of this Novelle with the drama, but unfortunately reveals himself in connection with St. Sylvesterabend as he did with Halm's Novelle, Das Auge Gottes, half of which Pachler unjustifiably suppressed in his published edition - to be somewhat deficient as a literary critic. As has been noted earlier, Pachler (together with Kuh) gives the entirely wrong date of composition for St. Sylvesterabend (i.e. 1835), and Pachler's claim that Halm's prose style in the later Novellen is markedly "knapp" is bizarre, since Halm, the mature "Novellist", is generally noted for his stylistic affiliation to the verbal "Verschachtelungen" (verbal boxes within boxes) of Kleist. Bennett, for example, sees strong stylistic affinities between the styles of Halm and Kleist, although notes that in Halm "the compact prose of Kleist is loosened" (Bennett 1961, 202).

Furthermore, Pachler's seeming view that an agglomeration "des Gräßlichen" (of the Horrid) should preclude publication of a literary work would logically see whole swathes of literary masterpieces - including many tales by Edgar Allen Poe and E.T.A. Hoffmann - censored and silenced.

Unlike Pachler, the author of the present article seeks to point up some of the skillful verbal and thematic structuring found in St. Sylvesterabend, which, coupled with the tale's vivid character-portrayal, justifies its inclusion in any discussion of Halm's literary achievements.

The plot of St. Sylvesterabend is relentless in its forward thrust and is simply told. It is set in Cologne, commencing on 30 December 1631 and spanning fewer than two days.

"Guardian" (Prior) Sebaldus of Cologne's Capuchin monastery entrusts humble Friar Placidus with an unusual commission; at 11 o'clock the following 
night, Placidus must go to the house of wealthy merchant, Egydius Kleeborn, who has long stood in a state of feud with his younger brother, Mauritius, a retired army colonel. In accordance with their deceased father's last will and testament, the conflicting brothers must come together each New Year's Eve in the presence of a monk and vow to abjure all future hostilities and to inaugurate a year of fraternal love. If in the course of the evening either brother insults or offends the other, a specified sum of money will be confiscated to the Capuchin monastery depending upon the severity of the transgression.

The following evening, Father Placidus makes his way to the sinister, blackdraped Kleeborn residence, where he is ushered into the unsettling presence of its master, Egydius Kleeborn, who curtly asks the monk who he is, and then promptly turns his back on him.

A few minutes later Egydius' younger brother, Colonel Mauritius Kleeborn, arrives accompanied by his valet, Philipp. After the ritual formula of exhortation and Bible reading (St. Paul's laudatio of Love) and blessings have been spoken by the friar, the latter instructs the brothers to sit together in friendly converse until the midnight hour strikes and the New Year is rung in - while he himself will sit alone outside the chamber until their meeting has concluded.

Left to themselves, the two brothers are unable to disguise their mutual hatred. Egydius bitterly recalls how Mauritius, due to his endearing physical appearance, had always been their parents' favourite, while Mauritius tells Egydius how the latter has ever been a sanctimonious hypocrite. Egydius hits back by deploring the hedonism of Mauritius's lifestyle, while the latter reproaches his older brother with dishonesty and selfishness. The mutual recriminations grow more lurid. Egydius reminds his younger brother of how he (Mauritius) had stolen away from Egydius the Venetian girl, Leonella, whom Egydius had desired; seeking revenge, Egydius had subsequently enticed away and ensnared Mauritius's own fiancée, Elsbeth. At this point, Egydius pulls back a black curtain from a deep alcove in the room, and with a burst of malicious laughter displays Elsbeth's corpse stretched out on a bier. Horrified, Mauritius is forced to hear more. Egydius tells him how he (Egydius) had purchased masses of Fugger equities and crashed the trading house in which Mauritius was a major shareholder, and then had set a Genoese gambling cheat upon him to rob him of his gaming wins. Mauritius, at this, reveals how he has already exacted vengeance, since he had long ago abducted Egydius's baby boy and reared him as a drunkard, whoremonger and highwayman; but Egydius has in turn responded by kidnapping Mauritius's bastard daughter from her mother, Leonella, and raising her as his own - a ploy which had hoodwinked Mauritius and caused him to steal the girl back many years later (not knowing that it was his own child) and force her into prostitution. When 
Mauritius now discovers the true identity of the girl, he lunges at his triumphant, smirking brother and reaches for his throat, while Egydius reaches for Mauritius's own.

Meanwhile, Father Placidus discovers that Mauritius's batman, Philipp, is his (Placidus's) brother, whom Placidus (formerly named "Georg") has not seen for thirty years: the two men had once loved the same woman, but Placidus had renounced this Ännchen out of consideration for his brother and left his native land to become a monk. Philipp had analogously performed an act of renunciation by relinquishing Ännchen to a wealthier man than himself, and had devoted his life to searching for his missing brother. Now the two are unexpectedly reunited and bask in their brotherly love.

At the stroke of 1 o'clock, the monk and his sibling enter the adjacent chamber to tell the Kleeborns that their meeting has concluded - only to find them dead, locked in a twisted embrace, their faces horribly distorted, with bulging eyes, eloquent of hate and maleficence. Father Placidus speaks words of benediction over their unsightly corpses, and his brother echoes these words with a solemn "Amen". As he does so, a gentle breeze stirs the heavy black drape around Elsbeth's lifeless body.

Resonances of the Biblical Cain and Abel Story and of Schiller's Die Räuber

The trope of the feuding brothers is ancient and extends back at least as far as the Biblical story of Cain's homicidal antagonism towards Abel.

This fraternal hatred is specifically referenced in Halm's Novelle when Mauritius declares to Egydius "dass ich dich hasse, mehr als Kain den Abel" (that I hate you more than Cain hated Abel) (Halm 2017, loc. 346). In the Biblical tale, Cain's murder of Abel is motivated by the jealousy which the older brother feels towards his younger sibling, who is more favoured of God; Halm echoes this in his story, as the older brother, Egydius, resents the greater love and affection bestowed on his younger brother, Mauritius, by their father - a pious but misguided Christian who would function in the complex of paternal-filial relations of this Novelle in loco dei.

Yet if the prototype of intense brotherly hatred is biblical, it is to a leading poet of the German Sturm und Drang and proto-romanticism that we must look if we wish to detect the strongest influence on the shaping of character in Halm's Novelle.

In the period when Halm was writing St. Sylvesterabend, his favourite Dichter was Friedrich Schiller. Halm revered him (even adopting his forename, 
"Friedrich", in his pseudonym of "Friedrich Halm"). He writes of his immense admiration for Schiller in his autobiographical essay, Sendschreiben an J.C.R. (Halm 2012, passim). It is evident that Halm's characterisation of the two brothers, Egydius and Mauritius, owes much to their Schillerian precursor, Franz von Moor. The lies, deviousness, viciousness, intemperate language, blasphemy and villainy which mark out Franz as a moral monster are all replicated in the personages of Halm's feuding siblings. Whereas Franz von Moor, however, is chiefly driven by a thirst for wealth and power, the brothers Kleeborn are actuated by mutual personal loathing. Each detests the other and wishes to have vengeance for wrongs suffered at the other's hands. Indeed, the craving for revenge is the obsessive and destructive motive force which propels the two brothers through their lives, each geared to the other in a kind of co-dependent rage. Obsession is a key and central focus in Halm's oeuvre, so this is thematically prefigurative. Whereas Mauritius resembles to some extent the passionate but ingenuous Karl Moor, Egydius comes closer to the cunning and calculating machinations of Franz Moor, who uses spurious logic and specious reasoning to justify his own horrific action of patricide. Mauritius deplores his brother's similar misuse of reason and intellect in the latter's push for revenge, saying, "du prahlst mit deinem alles berechnenden Verstande ..." (you boast of your all-calculating intellect) (Halm 2017, loc. 442). Such "Verstand" (intelligence/intellect) is not calculated to promote harmony and fraternal concord (as between Friar Placidus and his long-lost brother), but becomes a weapon of sneering superiority and scorn, as Egydius makes evident when he hisses at his sibling, "Verstand verachtet die Thorheit!" (Intelligence despises folly!) (Halm 2017, loc. 357).

Egydius is indeed reminiscent of Franz Moor in his cold use of "Witz" (wit/ intelligence) to compensate for his sense of denied parental love in contrast to his favoured brother (one notes the recurrent Cain and Abel motif). Early in Die Räuber, Franz remarks bitterly to his father:

Ihr seht, ich kann auch witzig sein, aber mein Witz ist Skorpionstich. Und dann der trockne Alltagsmensch, der kalte, hölzerne Franz, und wie die Titelchen alle heißen mögen, die Euch der Contrast zwischen ihm und mir mocht' eingegeben haben, wenn er Euch auf dem Schooße saß, oder in die Backen zwickte ... [Schiller 1781, loc. 547].

(You see that I can also be witty, but my wit is the sting of a scorpion. And then there was me, the dry, pedestrian, everyday man, cold, wooden Franz, and however else the epithets ran which the contrast between him and me might have suggested to you, when he sat on your lap and tweaked your cheeks ...). 
This could be a characterisation of Mauritius and Egydius Kleeborn, with the former's being presented as more personally endearing and attractive, while the latter is shown as intellectually brighter and more acerbic, yet more physically repellent. The one possesses qualities which the other lacks - and which he hates witnessing in the person of his own hostile brother.

Yet what of the specific themes and dynamics of Halm's Novelle? What are his central concerns in this sensationalist tale, and how do they manifest themselves imagistically and stylistically in the verbal weave of his text?

\subsection{Structural Links to Dramatic Form}

In terms of plot dynamics, the Novelle is broadly structured analogous to a fiveAct play - which is fitting for a writer who would later achieve fame precisely as a dramatist. If one analyses the outer form of the tale, one arrives at the following structure:

1) The exposition, in which Guardian Sebaldus tells Father Placidus of the Kleeborn brothers, their late father's will, and Placidus's own mission.

2) The rising tension, involving Father Placidus's encounter with the two hostile Kleeborn brothers and his pronouncing of the Pauline teaching of caritas

3) The two brothers' verbal conflict, reaching a high-point of violence

4) The turning point or mood-shift volta of the plot, taking the form of the reunion of Placidus (Georg) and his brother, Philipp

5) The catastrophe (the death of the two Kleeborn brothers).

The formal link with the drama continues in the lengthy passages of direct speech which constitute large stretches of text (a feature which would largely be dropped by Halm in his later Novellen, where he would display a predilection for indirect speech), and in the constant theme of conflict (the defining constituent of drama) which runs throughout the tale and is initiated by its very setting: a turbulent snow-storm and the violent Thirty Years War (specifically, the siege of Mainz, which calls the Guardian away from his monastery). Violence reaches its apogee in the brutal, Grand Guignol mutual murder of Egydius and Mauritius Kleeborn. In this work of prose fiction, Halm is effectively constructing a hybrid species of literature: a melodrama in Novelle form.

\subsection{Religious Themes and Motifs}

9.2.1 From his Earliest Stories to his Final, Mature Novellen

Friedrich Halm was intent on articulating religious/spiritual ideas. Dietrich Arendt's study of Halm's three best-known Novellen (i.e. Die Marzipan-Lise, Die 
Freundinnen [The Girl-Friends], and Das Haus an der Veronabrücke) rightly styles those works "religiöse Charakternovellen" (religious character-novellas) (Arendt 1953, 130).

Although nominally a Catholic, Halm was an independent liberal thinker in matters of religion "Zeitlebens war er freisinnig in Bezug auf Politik und Religion", (Throughout his life, he was a free thinker/ liberal in matters of politics and religion) (Pachler 1877, 238). Halm's never-diminishing admiration of the doctrines of Christ did not preclude a brave preparedness to criticise the Catholic Church, including former Popes (Pope Gregory IX is markedly vilified in Das Auge Gottes). St. Sylvesterabend very much forms part of this pattern. Spiritual notions lie at its heart, but a key representative of the Catholic Church meets with Halm's unmistakable disapprobation.

The religious motif is sounded within the first lines of the story's opening when reference is made to the devout Cologne crowds returning from Vespers and streaming out of the numerous churches (Halm 2017, loc. 80). One notes, however, that a spiritual/worldly dichotomy is established in those first few lines when, after the mention of Vespers, the secular "überfüllten Schenken" (over-crowded taverns) are referenced, as well as the "verworrene Gemenge vieler Stimmen" (confused jumble of many voices) (Halm 2017, loc. 84) issuing therefrom, reminiscent of the Tower of Babel, to which Father Placidus will later allude (Halm 2017, loc. 207). With reference to the "over-crowded taverns", it is not without significance that the Kleeborn brothers are later both portrayed as excessive imbibers of alcohol.

Regarding the motif of violence, the story is significantly located at the time of the Thirty Years' War. Just one week before the opening of the narrative, the Lutheran king, Gustavus Adolphus of Sweden, has been laying siege to Mainz (from 17 to 22 December 1631), and more generally Germany had been ravaged by successive waves of foreign troops. Many of these soldiers were mercenaries in quest of gold, and it is the compulsive greed for gold (later most signally enacted in Halm's alchemical drama, Der Adept, as well as in the religious Novelle, Das Auge Gottes) which sounds the key-note of Halm's critique of the Roman Catholic Church.

The Guardian of the Capuchin monastery in Cologne, Father Sebaldus (his ancient Germanic name appropriately meaning "victory through force"), is depicted as a corpulent, bullying, self-indulgent, worldly man with flashing eyes, ostentatious beard, and a hot temper. His sole preoccupation is the accumulation of money - which is particularly ironic in view of the fact that the Capuchin brotherhood was instituted as an especially austere and poverty-observing Order. The Guardian, however, eulogises the power of money - rather than pious prayer and the Word of God - to "achieve the impossible," as he says, 
commenting that “... die Macht des Goldes reicht weiter als der Arm und die Blicke - und oft weiter als frommes Gebeth und das Wort Gottes" (... the power of gold extends further than arm and eye - and often further than pious prayer and God's Word) (Halm 2017, loc. 126).

Not only does this prelate's itching for gold and silver (from the coffers of the Kleeborn brothers) cast a condemnatory shadow across his pretended piety, but his behaviour is in fact void of all humility and benignity. He keeps humble Father Placidus waiting a full half hour before deigning to acknowledge his presence in the cell (Halm 2017, loc. 106) - and when Placidus dares to protest his unsuitability for the task assigned to him, the Guardian cuts him off with the trenchant command to do as he is ordered (Halm 2017, loc. 190) and to remain silent (Halm 2017, loc. 194). There is no Christian patience or benevolence discernible in this hypocritical Prior's character.

Contrasted with the imperious Guardian is Father Placidus himself. He is diffidence and humility personified (his Latin name means "the placid one"). Yet for all his selflessness, he is on occasion fired by Christian fervour to speak out against acquisitiveness. He despises money (Halm 2017, loc. 161) and even castigates the builders of the as yet uncompleted Cologne Cathedral (it was only completed in 1880), saying that they were driven not by love and piety, but solely by enthrallment to gold, "wenn noch Liebe an diesem Münster baute und herzinnige Frömmigkeit, seine Thürme ragten lange vollendet in den Lüften; aber seit sie nur Gold dienen, will es nicht mehr von der Stelle!" (if love were building this minster and heartfelt piety, its towers would long ago be reaching up into the sky; but since they serve only gold, it will advance no further!) (Halm 2017, loc. 207). Whereas the Guardian is characterised by money-fixated "Unruhe und Besorgnis" (restlessness and worry) (Halm 2017, loc. 89), Placidus is filled with "menschenfreundliche Sorge" (humanitarian caring) (Halm 2017, loc. 506) and his heart is "von weltlichen Begehren gereinigt")(cleansed of worldly desires) (Halm 2017, loc. 506). Unlike Sebaldus, Placidus does not lust after money; he even lets opportunities for its acquisition pass him by, refusing to impose harsh monetary penalties on the Kleeborns for their infractions. In this his inner nature accords with the Capuchin rule of poverty. The Guardian, by contrast, regards the collecting of the Kleeborns' penitential monetary forfeits as "dieses hochwichtige Geschäft" (this highly important business) (Halm 2017, loc. 152) - literally a "business", a money-making venture which "mir gar sehr am Herzen liegt” (is very dear to my heart) (Halm 2017, loc. 89).

Further, Halm bifurcates the religious world into those who are spiritually orderly and uncluttered (Placidus) and those (notably the Guardian) whose self-created immediate environment is one of "chaotische Verwirrung" (chaotic disorder) (Halm 2017, loc. 88) This links back to the "verworrene Gemenge 
vieler Stimmen" (confused jumble of many voices) (Halm 2017, loc. 84) which typifies the profane environment of the taverns. Analogously, Guardian Sebaldus has summoned a team of horsemen to his monastery, to accompany him on his journey to Mainz. Those secular riders shatter the peace and orderliness of the cloisters when they enter - displaying no respect for monastic sanctity. We read, "Die schweren Flügel des Klosterthores hatten sich ächzend in ihren Angeln gedreht, das grasbewachsene Pflaster des Hofes dröhnte von dem Hufschlag mehrerer Roße, und die lauten Stimmen ihrer Führer widerhallten in den Gewölben der Kreuzgänge." (The heavy monastery gates had turned groaningly on their hinges; the grass-grown courtyard resounded to the hoof beats of a goodly number of steeds, and the loud voices of their leaders reverberated in the vaults of the cloisters) (Halm 2017, loc. 169). In this tale, the sphere of the spiritual suffers a noisy incursion from the sphere of the temporal.

Another contrast between Sebaldus and Placidus lies in the fact that the Guardian's eyes are always dry, never moist, and directed downwards - at his desk, at the documents in his hands concerning the collecting of money, and sneeringly down upon humble Placidus. Not once does Sebaldus cast his gaze upwards to Heaven. Placidus does. Placidus also cries. Both are frequent signs in Halm of a humane, spiritually attuned heart and relatedness to the Divine (Page 1988, 322-327). When Placidus reluctantly leaves the two feuding Kleeborn brothers alone in their meeting room, he exits with a tear glistening on his cheek (Halm 2017, loc. 502) and "seine zum Himmel emporgerichteten Augen betheten um einen Strahl ewigen Lichtes für die tiefe Nacht in den Gemüthern der beyden Brüder. So stand er eine Weile, der Erdenwelt entrückt..." (his eyes, directed up towards Heaven, prayed for a ray of eternal light to enter the dark night of the two brothers' souls. Thus, he stood a while, lifted out of this earthly world...) (Halm 2017, loc. 505). The Guardian, by contrast, is never moved, transfigured or transported from the world. He is wholly enmeshed within it.

\subsubsection{Corinthians $1 / 13$}

As a thematic counterpole to the avarice and uncharitableness of Sebaldus and the Kleeborn brothers, Halm inserts into his narrative St. Paul's celebrated dithyramb to Love (agape / caritas): 1 Corinthians 13. Significantly, Halm places the exalted passage at the physical centre of the Novelle. It functions as the moral and spiritual yardstick against which all persons in the tale must be measured. Furthermore, Halm appears to use his own translation of the text - not that of Luther, nor of Leander van Eß, nor of Johann Friedrich von Meyer (the best-known German versions of the Bible current at the time in Austria and which were heavily based on Luther, as were other Catholic "Korrekturbibeln" - corrected Bibles). One can see from this that Halm accorded 
high significance to this passage and wanted it rendered in a way that would best express the spiritual message of his story.

If we compare Halm's translation (note that the accuracy of the translation is not at issue here, but the relevance of its emphases and syntactical shaping for St. Sylvesterabend), we note the following differences from Luther and the Luther-based versions mentioned above: whereas Luther (1545), Eß (1807), and Meyer (1819), after the conditional postulations of "if I spoke with the tongues of angels" etc., use the phrase (or close variants), "und hätte der Liebe nicht" (and had nothing of love) (Luther 1545; Meyer 1819; Eß 1807), where the partitive genitive tends slightly to weaken the full force of the concept of Liebe (love) and where Liebe is relegated to the end of the clause, Halm foregrounds Liebe, highlights it, and leaves it undivided by any partitive-genitival construction, writing, "die Liebe aber nicht hätte" (Love, however, not possessing) (Halm 2017, loc. 292). Love literally becomes here the first concept proclaimed, whole and undivided, after the preceding conditional clauses. In other words, Halm is intensifying still further what is already a fervent paean of caritas.

Analogously, where Luther (1545), Eß (1807), and Meyer (1819) write, "mit Menschen- und mit Engelzungen redete" (or similar - Luther 1545; Meyer 1819; Eß 1807) (spoke with the tongues of humans and angels), Halm uniquely inserts the word alle (all), "die Sprachen aller Menschen und Engel redete" (spoke the languages of all humans and angels), which again intensifies and superlativises, as it were, the concept.

Moreover, where Luther and his successors (Luther 1545; Meyer 1819; Eß 1807) select the preposition unter (amongst) when speaking of Love's being the greatest quality amongst Love, Faith and Hope, writing "aber die Liebe ist die größte unter ihnen" (but love is the greatest amongst them), Halm employs the preposition aus (out of), "die Liebe ist aber die größte aus ihnen" (love is, however, the greatest out of them) (Halm 2017, loc. 303), which conveys the sense of Love's being lifted up separately out of the line-up of the three pre-eminent qualities and raised to a truly exalted, unique status. It stands alone - it is transcendently "out" of all other comparisons and equivalencies.

Finally, where Luther and Meyer write, "aber die Liebe ist die größte unter ihnen" (but love is the greatest amongst them) (Luther 1545; Meyer 1819), and Eß writes, "aber die größte unter diesen ist die Liebe" (but the greatest amongst them is love) (Eß 1807), Halm allows no conjunction to stand in the way of Liebe (love), but immediately brings it centre stage, declaring, "die Liebe ist aber die größte aus ihnen" (love is, however, the greatest out of them) (Halm 2017, loc. 303). Christian agape thus stands unobstructed at the very core and centre of the story's moral proclamation. Love - or its absence, when ousted by monomaniacal vindictiveness - constitutes the beating heart of this tale. 
How do the Kleeborn brothers acquit themselves in comparison with the august exemplum of Pauline love placed before them? Their lives serially enact the diametrical opposite of the spiritual injunctions enjoined by the Biblical passage. The brothers invert all the sagely advice of which they become (unwilling) auditors. The Biblical passage speaks of love thus, in Halm's translation:

und wenn ich alle meine Habe und Speise den Armen austheilete, und meinen Leib zum Verbrennen dargäbe, die Liebe aber nicht hätte, so hülfe es mir nichts; die Liebe ist geduldig, sie ist gütig, die Liebe beneidet nicht, sie handelt nicht leichtsinnig, sie bläst sich nicht auf, sie ist nicht ehrgeitzig, nicht eigennützig, nicht jähzornig, sie denkt nichts Arges, sie erfreut sich nicht über die Ungerechtigkeit, sondern über die Wahrheit; sie leidet alles, sie glaubet alles, sie hoffet alles, sie duldet alles. (Halm 2017, loc. 296-299).

(and if I distributed all my possessions and food to the poor and offered up my body for burning - love, however, not possessing - then it would avail me nothing; love is patient, it is kindly; love is not envious, it does not act improvidently; it does not puff itself up, it is not ambitious, not selfish, not quick to anger; it thinks no bad, it takes no delight in injustice, but in truth; it suffers all, it believes all, it hopes all, it endures all.)

The two brothers do the precise reverse of this. Egydius boasts of how he has distributed alms (Halm 2017, loc. 413) - and yet this action is spiritually empty since it is performed without love and is motivated by selfishness (it is eigennützig); both brothers - like the Guardian - display a notable lack of patience (the Geduld which St. Paul praises), frequently bursting out into furious Rodomontaden (vain boasting and bluster) (Halm 2017, loc. 341) against the other's wickedness (they are jähzornig); they know no Güte (kindliness), seeking only to harm each other; they constantly beneiden (envy) each other's attributes and attainments, and yet puff themselves up with the cleverness of their vengeful schemes; they are full of personal ambition (ehrgeitzig) and are rash and reckless (leichtsinnig) in their actions; they do nothing but denken Arges (think bad) of each other, and delight at any Ungerechtigkeit (injustice) which they can perpetrate and at any truth they can conceal; they do not leiden alles (suffer all), they do not have faith in God or one another, and hope only for evil. They are anti-caritas incarnate.

Father Placidus and his sibling, Philipp, however, embody the qualities which St. Paul exalts. It is noteworthy that in the expositional section of the Novelle, Placidus tells his Superior (Sebaldus) of the loving bond that should 
unite two brothers: "Das Band, das Brüder vereint, ist aus Liebe gewoben, und Neigung legt ihre Hände in einander, und Sehnsucht verschließt ihre Arme" (The bond which unites brothers is woven of love, and affection places their hands into one another, and longing closes their arms in embrace) (Halm 2017, loc. 161). At the end of the story, when the long-lost brothers reunite, these words become action incarnate as Georg (Placidus) takes Philipp into his arms. We read, "er breitete die Arme weit aus, und preßte mit rascher heftiger Bewegung den Bruder an sein Herz, entfernte ihn dann wieder von sich, um ihn zu betrachten, schloß ihn dann wieder stürmischer in seine Arme" (he stretched his arms out wide and pressed his brother in a quick and vigorous movement to his heart, then removed him from himself again a distance in order to contemplate him, and then closed him in his arms again more stormily) (Halm 2017, loc. 508), and later: "[u]nd die Brüder umarmten sich, und küßten und herzten sich" (and the brothers embraced each other and kissed and hugged each other) (Halm 2017, loc. 530). One notes, too, that Placidus steps back from his brother, all the better to see him clearly and lovingly with a degree of the benign detachment which philosopher Edward Bullough terms psychical distance (Bullough 1912, 87) - whereas the Kleeborns end their lives in a rigid, close-up, contorted death-grip from which all clarity of loving vision is precluded.

The programme of obsessive hatred to which the Kleeborns cleave is centred upon the fixation of seizing or withholding a mutually desired woman or child from the other. Employing reverse imaging, Halm has brothers Georg and Philipp, in their younger years, love the same girl, but unlike the Kleeborns Georg renounces Ännchen for fear that his brother will pine away out of unrequited love, while Philipp renounces Ännchen to search far and wide for his long-lost brother.

It would be tedious to rehearse again all the qualities of love which St. Paul exalts, but it will easily be seen that Georg and Philipp enact them in rich measure; where the Kleeborns serve self, Georg and Philipp serve, and make sacrifices for, the other; where the Kleeborns are vainglorious and swaggering, Georg and Philipp are modest and humble; where the Kleeborns think only ill of each other, Georg and Philipp think only benevolent thoughts; where the Kleeborns believe in Hell and not Heaven (Halm 2017, loc. 468) and end their days hatefully looking back on a life destined for damnation, Georg and Philipp believe in Heaven and are hallowed, transfigured and made spiritually whole by their own self-sacrificial goodness and unfeigned, proven love, "ihre treue unerkünstelte Liebe, geprüft durch schwere Opfer, gereift durch lange Trennung verklärte sie mit dem Schimmer einer tiefen heiligenden Zufriedenheit, die nur der Rückblick auf ein wohlverbrachtes Leben gewähren kann" (their true, 
unfeigned love, tested by heavy sacrifices, matured through long separation, transfigured them with the glow of a deep, holy content, which only the retrospective vision of a well-spent life can grant) (Halm 2017, loc. 537).

It can already be seen that Halm has structured his tale very carefully along a pattern of parallels and contrasts. This structuring principle continues throughout the Novelle.

\subsubsection{Motivic and Verbal Parallelisms}

The setting of the first section of the Novelle is the Guardian's cell, where this uncharitable and money-hoarding monk sits at a table covered with a green cloth (Halm 2017, loc. 88). Green is the traditional colour of dragons (cf., for example, the Dutch painter Hendrik Goltzius' famous painting, Cadmus Slays the Dragon), reptilian creatures who in Germanic legend hoard and guard gold (note the fitting name of the "Guardian"!). The colour green - the colour of reptiles, and often of demons in Western art - becomes significant when Halm links it to the setting of the second half of the Novelle, which takes place precisely at the "Haus zum grünen Drachen" (house of the Green Dragon) (Halm 2017, loc. 154 and 203), a house which bears over its entrance the sculpted image of a green dragon with symbolically malformed wings (Halm 2017, loc. 211). Snakes and dragons are linked in Christianity to Satan (Biblically portrayed as a "snake" or "dragon"), so that the Kleeborns' meeting of twisted and internecine hatred will suitably play out under the aegis of evil, perversion, greed, and jealousy (Shakespeare's 'green-eyed monster'). Each brother speaks not only of wishing to guard his gold and silver, but also of wanting to vent his poisonous hatred upon his sibling rival. Significantly, Mauritius tells his brother how he longs to possess the poisonous and vitiating breath of a basilisk (a monstrous serpent-being) (Halm 2017, loc. 328) and how both brothers should fittingly "zischen wie Schlangen" (Halm 2017, loc. 339) (hiss like snakes) in their discourse. Consistent with this reptilian theme, Mauritius calls Egydius a viper (Natter, Halm 2017, loc. 482), as the tale moves towards its horrifying climax.

Parallelism continues: both the Guardian and Egydius Kleeborn are depicted as hypocrites. Guardian Sebaldus is indicated to be a self-indulgent man of stout figure, a "rüstige[r] wohlbeleibte[r] stattliche[r] Mann mit vollen glänzenden Wangen" (a lusty, corpulent, stately man with full shining cheeks) (Halm 2017, loc. 103-106) and "mit kleinen blitzenden Augen" (with small, glittering eyes) (Halm 2017, loc. 106), as is Egydius Kleeborn, with his darting eyes and aufgedunsene [s] Antlitz (bloated face) (Halm 2017, loc. 237). Both men are draped in robes, both are styled stattlich (stately) (Halm 2017, loc. 103 and 233), both are marked by agitation and restlessness of mind (far from the Biblical 
"peace that passeth all understanding") and both present themselves as what they are not, the one posing as a "poor" monastic, while intent upon amassing gold, the other being a sanctimoniously pious person who wears the mask of Christian virtue but is in reality a vicious dissembler of immense proportions and sinfulness. Both men are equally autocratic, disdainful and haughty, Sebaldus pointedly ignoring Placidus for half an hour when the latter enters his cell, forcing Placidus to wait, "da der Guardian ihn nicht beachtend in seiner Beschäftigung fortfuhr" (for the Guardian carried on with his business, paying no heed to him) (Halm 2017, loc. 96, emphasis added), while of Egydius we read, "Nach diesem Wort schritt er, den Mönch nicht weiter beachtend, in dem Gemache auf und nieder" (After these words he paced up and down the chamber, paying the monk no further heed) (Halm 2017, loc. 237, emphasis added). Halm is at pains by means of such parallelisms to intermesh the spheres of the secular and the faux-spiritual and to delineate how the one aspires to the overweening, tyrannous grandeur of the other, and how that other lapses into the agitated avarice of the worldly. Both stand in marked contrast with the sincere, diffident simplicity of Father Placidus.

Parallelism extends into the sphere of atmospherics, sonics and even lighting: inside Sebaldus's cell a "Lampe erleuchtete mit mattem Schimmer die Spitzbögen der Zelle" (a lamp lit the pointed arches of the cell with a dull glow) (Halm 2017, loc. 88), and at the Kleeborn house Placidus finds himself "in einem düsteren von Weihrauchwolken durchqualmten Raume" (in a gloomy incense-filled room) (Halm 2017, loc. 222), where the light is only spärlich (sparse) (Halm 2017, loc. 222) and is absorbed by a black drape bedecking the walls and dark wood of the ceiling. This is the gloom of non-enlightenment, of the benightedness of the soul, and of death (a corpse is laid out in the adjoining room) - just as Prior Sebaldus embodies in his gloomy chamber the immolation of true spirituality in thrall to greed.

Inside the Kleeborn meeting room, which evokes a counterfeit monastic cell, Egydius walks up and down resembling a robed monk, and just as the silence of the monastery is shattered by the noisy arrival on horseback of the Guardian's secular escort to Mainz, so the silence of the Kleeborn house is shattered by the tempestuous arrival of Mauritius Kleeborn and his servant, Philipp. As Sebaldus had stood up - "richtete sich in seiner ganzen einschüchternden Größe empor" (raised himself up in his full intimidating height) (Halm 2017, loc. 187) - to intimidate Father Placidus, so too does Egydius, "indem er sich emporrichtete" (raising himself up) (Halm 2017, loc. 313), inveigh against the monk; and just as Placidus had left the Guardian's room browbeaten and cowed, (Halm 2017, loc. 194), so too does he retreat from the Kleeborn meeting 
chamber, intimidated and glared at by the militant Mauritius (Halm 2017, loc. 320 ), who is eager verbally to savage his abhorred and abhorrent brother.

Halm is intimating through such parallels that just as the sphere of the monastery has lapsed into the arena of the worldly, so too has the arena of the worldly assumed a hue of perverted religiosity (the Kleeborn house stands directly beside the Cathedral, one notes; Halm 2017, 114) - the hue of intolerance and hatred. The wealthy Kleeborn house has become the locus of an unbalanced craving for revenge, just as the "poor" monastery under Sebaldus has become the locus of a misplaced craving for gold. Psychological and spiritual values are here mirrored and inverted.

It is also requisite at this juncture to look briefly at the role of words in this Novelle: the late Cornelius Kleeborn and Brother Placidus use words (St. Paul's panegyric to love) to bring feuding brothers into harmony. The Kleeborn siblings, however, use words as weapons, to wound and lacerate each other's souls through mutual recriminations and denunciations. Mauritius, in one of his "rodomontades", declares to his brother:

meine Worte sollen wie Lavatropfen in deine Seele brennen; ich will dir Dinge erzählen, die deine besten Gefühle auf die Folter spannen, die das Mark deiner Gebeine erschüttern, die dir das Herz zerreißen sollen ... (Halm 2017, loc. 332)

(my words shall burn into your soul like drops of lava; I want to tell you things that will stretch your best feelings upon the rack of torture, things that will shake your bones to the marrow and rend your heart to pieces ...).

Egydius retorts:

Warum soll ich die Worte zurückdrängen, die brennend auf meiner Zunge schweben, warum soll ich die Larve nicht wegwerfen, die mich beengt? Ja ich will auch reden, wie du redetest, ich will dir auch sagen, daß ich dich haße, daß ich dich verabscheue. Wer machte mich zum Heuchler? Wer machte mich zum Betrüger, zum ränkespinnenden Gleißner? Du und wieder du! (Halm 2017, loc. 392-396)

(Why should I suppress the words which hover burning on my tongue? Why should I not cast aside the mask which constricts me? Yes! I, too, wish to speak, as you spoke; I, too, want to tell you that I hate you, that I abhor you. Who made me a hypocrite? Who made me a deceiver, a cunning, calculating dissembler? You - and again you!). 
Monk Placidus does the precise opposite: he attempts to use pacifying words to build bridges of empathetic communication and reconciliation between the hostile brothers (Halm 2017, loc. 307-313); likewise, he and his own brother, Philipp, employ words to express sympathy, empathy and love - not antagonism or hatred (loc. 512-530).

It therefore strikes the reader as unexpected, perhaps, when Placidus Christian caritas made manifest - displays a degree of scepticism towards the late Cornelius Kleeborn's testamentary will. Placidus says of it, "das Testament hier in meinem lieben Ärmel kommt mir vor wie der Grundriß zum Thurme Babels! " (the testament here in the folds of my dear robe strike me as the veritable ground-plan for the Tower of Babel!) (Halm 2017, loc. 207). This is because the testament (Biblically pregnant word!) is hybrid, combining conflicting tranches of discourse - the laudable language of St. Paul adulterated with the language of the merchant, policeman or lawyer: financial penalties and strictures are threatened against the two sons if they fail to love each other as demanded. Each must incrementally forfeit a portion of his wealth for every act of unkindness committed against the other. If such maleficence is avoided, money will be saved. This effectively denigrates love into a business transaction (just as Guardian Sebaldus had spoken of this occasion as "dieses hochwichtige Geschäft," Halm 2017, loc. 176, emphasis added - "this highly important business"). Earlier in the Novelle, Placidus had lamented money's being such a cold thing, which should not be used as a tool to reconcile two hostile brothers - yet that is precisely what Old Kleeborn attempts. It thus earns the censure of the pure-hearted Capuchin monk.

Furthermore, whereas St. Paul's vision of love is of a freely bestowed and spontaneous force, Cornelius Kleeborn tries to regulate the enactment of love through all manner of dictates and prohibitions. Love for Cornelius Kleeborn means unswervingly following the testamentary law which he has had drawn up by the most eminent lawyers of the Holy Roman Empire (Halm 2017, loc. 147). He wants both the monk who presides over the brothers' meeting and the brothers themselves to follow his legally codified orders to the letter. The Guardian instructs Placidus in the following terms:

Ihr werdet in dem Testamente des seligen Kleeborn, das ich euch hiermit übergebe, genau angegeben finden, wie jeder von den beyden Brüdern den andern zu begrüßen und welche Sprüche er herzusagen hat. Auch das Benehmen des geistlichen Aemmissarius ist genau vorgeschrieben. Haltet euch darnach, und treibt die Büßen, mit denen der Zorn des Vaters den Ungehorsamen bedroht, zu Günsten und Ehren unseres Klosters gewissenhaft ein. (Halm 2017, loc. 176-180) 
(You will find precisely specified in the testament of the late Kleeborn, which I herewith hand over to you, exactly how the two brothers are to greet each other and what words they are to pronounce. Even the behaviour of the spiritual emissary is precisely prescribed. Hold fast to that, and scrupulously collect the punitive fines with which the anger of the father has threatened the disobedient - for the benefit and honour of our monastery.)

Genau angegeben (precisely specified), Sprüche hersagen (words to be pronounced), genau vorgeschrieben (precisely prescribed), Büßen eintreiben (collect the fines), Zorn (anger), den Ungehorsamen (the disobedient): there is no room here for the free play of creative, generous and spontaneous love (as we see enacted by Placidus and Philipp). Everything here must be done according to the book - and it is a lawyer's or rule-master's book, not that of an Apostle.

That is why Placidus remains sceptical of the value of the Kleeborn will. And that is why Cornelius Kleeborn's misguided attempt to direct affairs from beyond the grave - for all his benign intentions - proves tragically abortive.

St. Sylvesterabend is the earliest extant, complete Novelle which we possess from the pen of Friedrich Halm. After writing it (and before resuming contact with Enk von der Burg in 1831), Halm wrote several more stories. Subsequent to Enk's virulent attack on the tale, Halm's fiction-writing completely ceased - for decades.

Although part of Halm's juvenilia, St. Sylvesterabend yet displays an eye for structural and thematic detail which deserves our respect. It treats of themes which were to preoccupy Halm for the duration of his life, particularly obsessive entrapment within an all-consuming craving, and the contrasting inner liberation enacted through self-sacrificial love. Here the monomania highlighted is the feverish craving for revenge. This theme will find its apotheosis in Halm's arguably greatest Novelle, Das Haus an der Veronabrücke, written just six years before his death. There the anti-hero, Ruggiero Malgrati, thirsts for vengeance upon his insubordinate nephew, Anselmo. This all-consuming idée fixe eventually drives Ruggiero into madness and suicide.

In St. Sylvesterabend, too, the central villainous characters - the Kleeborn brothers - are held in the tight grip of a monomania which unhinges their sanity, ravages their morality, and propels them into grisly, mutual murder. This is 
the abiding preoccupation of Halm; the psychical dangers inherent in clinging too passionately and obsessively to a goal which dislodges morality and displaces all other values from one's life (Halm's constant wariness and warnings regarding passionate clinging in the face of life's temporality have a Buddhist hue to them). It is first enunciated here in this melodramatic Novelle, St. Sylvesterabend, and will later find renewed expression through such characters as Ruprecht von Rossum, the impoverished protagonist of Das Auge Gottes, who yearns for a return of his family's former glory, and Sampiero, the eponymous hero of that drama, the Corsican freedom fighter who allows love of country to oust love of wife - and even causes him to murder that wife in the name of his psycho-pathologically twisted vision of patriotism. In contrast to such types stand those inspired and actuated by Love: Bertha (Ruprecht's wife), Vanina (Sampiero's spouse), Ambrosia (Ruggiero's wife), and humble Father Placidus.

In St. Sylvesterabend, Halm further shows himself already a youthful master of the "Gothically" atmospheric: his depiction of the sinister Kleeborn House of the Green Dragon, with its black drapes on its walls and dark, light-devouring ceiling, its mysterious distant murmuring of prayers, its wreaths of heavy, oppressive incense, and its corpse lying secretly stretched out behind an alcove curtain, which on occasion stirs with ghostly movement - all this is portrayed with simple, yet tension-building effectiveness. Anton Schlossar writes of Halm's Novellen in general:

Alle novellistischen Stücke Halms weisen ein ernstes, oft düsteres, unheimliches Gepräge auf; ein fatalistischer Zug macht sich darin bemerkbar. Aber die Gestalten treten überall plastisch hervor, die Handlung fesselt stets, die Zeichnung der landschaftlichen Umgebung ist vorzüglich ausgeführt ... [und] die Schauplätze ... mit bewundrungswürdiger Anschaulichkeit geschildert. (Schlossar 1904, vierter Band: 4).

(All of Halm's novellas bear a serious, often gloomy, uncanny stamp; a fatalistic feature is discernible in them. But his figures everywhere step forth in rounded three-dimensionality; the action is always gripping, the depiction of the surrounding landscape is splendidly realised ... [and] the scenes of the action .... are presented with admirable vividness.).

This is well embodied in St. Sylvesterabend. The two vividly depicted feuding siblings, who appear almost as exudations of the sinister House of the Green Dragon, seem to surge towards their horrible end, borne along on a floodtide of fateful hatred which can only terminate in disaster. Their fate is not "in their stars", but is self-generated, lying in the viciousness and arrogance of their 
hearts. As Halm himself once elucidatingly wrote of his works' central themes, "ich suche die sittliche Weltordnung darzustellen, wie ein Individuum dagegen ankämpft und weil es sich vermessen darüber stellt, tragisch notwendig untergehen muß" (I seek to portray the moral world-order - how an individual fights against it and, because he hubristically places himself above it, must of necessity tragically perish) (Schlossar 1904, 90). The Kleeborn brothers possess spiritual Vermessenheit (hybris) in shameful plentitude - and that is why in Halm's moral universe they must, of necessity, untergehen (go under).

While Enk von der Burg in his programmatic pushing of Halm towards the drama (rather than prose fiction) chose to savage the grammar, syntax and plot of this Novelle and mercilessly undermined the novelistic confidence of its young creator, thus potentially robbing Austrian literature of later valuable prose-fiction works, and while Faust Pachler chose to exclude the tale from publication on account of its "Uebereinanderhäufung des Gräßlichen" (piling up horrid upon horrid), it is to be hoped that Germanist scholars and students in the 21st century will not be so squeamish and will pursue a more probing and discerning style-contentual analysis of this novella. The present article constitutes an initial commencement in that direction.

St. Sylvesterabend, it may be concluded, not only possesses value as a thematically/stylistically well structured, atmospheric, melodramatic, sensationalist Novelle in its own right, but equally presents to the literary historian's surveying eye the early prefigurative stirring and burgeoning of creative seeds which would subsequently burst into full bloom and rich fruit in Friedrich Halm's later prose-fictional masterpieces. It provides an alluring foretaste of the striking talent that was yet to come.

\section{References}

Allan, Sean. 2001. The Stories of Heinrich von Kleist: Fictions of Security. Rochester: Camden House.

Arendt, Dietrich. 1953. Das novellistische Werk Friedrich Halms. Marburg: Universität Marburg.

Bennett, E.K. (Waidson, H.M., reviser). 1961. A History of the German Novelle: From Goethe to Thomas Mann. Cambridge: Cambridge University Press.

Brown, Lesley (ed.). 2003. The Shorter Oxford English Dictionary, Vol. 2, Fifth Edition. New York: OUP.

Bullough, Edward. 1912. "Psychical Distance" as a Factor in Art and as an Aesthetic Principle'. British Journal of Psychology, Vol. 5. Oxford: Wiley-Blackwell: 87-117. 
Encyclopaedia Britannica. 2018. (https://www.britannica.com/art/literary-sketch, consulted 7.7.18).

Eß, Leander van. 1807. Die heiligen Schriften des Neuen Testaments. URL: http://www .glaubensstimme.de/doku.php?id=autoren:v:van_ess:bibel.

Durbridge, Francis. 30 October 1942. Paul Temple Intervenes. London: ввС radio broadcast.

Garland, Henry and Mary. 1986. The Oxford Companion to German Literature. Oxford: Oxford University Press.

German Free Dictionary, 2018 (https://de.thefreedictionary.com/Skizze; consulted 7.7.18).

Halm, Friedrich. 1856. Die Marzipan-Lise. In 'Unterhaltungen am häuslichen Herd', ed. Gutzkow, Karl. Leipzig: Brockhaus.

Halm, Friedrich. 1872a. Friedrich Halm's Werke, Band $n$ (ed. Pachler, Faust and Kuh, Emil). Vienna: Carl Gerold's Sohn.

Halm, Friedrich. 1872b. Friedrich Halm's Werke, Band 12 (ed. Pachler, Faust and Kuh, Emil). Vienna: Carl Gerold's Sohn.

Halm, Friedrich. 2011. Das Auge Gottes. Transcribed and edited by Dr. Tony Page. Bangkok: Blade Publications, Amazon Kindle Edition.

Halm, Friedrich. 2012. Sendschreiben an J.C.R. Transcribed and edited by Dr. Tony Page. Bangkok: Blade Publications, Amazon Kindle Edition.

Halm, Friedrich. 2017. St. Sylvesterabend. Transcribed and edited by Dr. Tony Page. Bangkok: Blade Publications, Amazon Kindle Edition.

Halm, Friedrich. 2018. New Year's Eve. Translated by Dr. Tony Page. Bangkok: Blade Publications, Amazon Kindle Edition.

Heyse, Paul. 1871. Deutscher Novellenschatz. Munich: R. Oldenbourg Verlag.

Joyce, James. 2000. Portrait of the Artist as a Young Man. Oxford: Oxford University Press.

Kosch, Wilhelm (ed. Berger, Bruno). 1963. Deutsches Literatur-Lexikon. Bern and Munich: Francke Verlag.

Luther, Martin. 1545. Die Bibel. URL: http://www.jesus-is-lord.com/germicor.htm (consulted 10.10.18).

Marx, Karl, and Engels, Friedrich. 1969 (orig.1846). Die deutsche Ideologie. Berlin/DDR: Dietz Verlag.

Meyer, Friedrich von. 1819. Die Bibel URL: https://opacplus.bsb-muenchen.de/ metaopac/search?oclcno $=642715749 \& \mathrm{db}=100$ (consulted 10.10.18).

Pachler, Faust. 1877. Jugend- und Lehrjahre des Dichters Friedrich Halm. Vienna: Carl Gerold's Sohn.

Page, Tony. 1988. Friedrich Halm's Das Auge Gottes: An Analysis of the Complete Text. Oxford D.Phil. Dissertation. 
Pochlatko, Herbert, Josef Pongratz, and Karl Koweindl. 1963. Einführung in die Literatur des deutschen Sprachraumes von ihren Anfängen bis zur Gegenwart, Band 2. Vienna: Wilhelm Braumüller Universitäts-Verlagsbuchhandlung.

Reinecke, Charlotte. 1912. Studien zu Halms Erzählungen und ihrer Technik. Tübingen: Verlag von J.C.B. MHR (Paul Siebeck).

Schachinger, Rudolf. 189o. Briefwechsel zwischen Michael Enk von der Burg und Eligius Freiherrvon Münch-Bellinghausen (Friedrich Halm). Vienna: Holder.

Schiller, Friedrich. 1781. "Die Räuber. Ein Schauspiel." In Sämmtliche Werke von Friedrich von Schiller. Delphi Classics 2012.

Schlossar, Anton. 1904. Friedrich Halms ausgewählte Werke in vier Bänden. Leipzig: Max Hesse's Verlag.

Wilpert, Gero von. 1976. Deutsches Dichterlexikon. Stuttgart: Alfred Kröner Verlag. 